\title{
L- and T-type calcium channels control aldosterone production from human adrenals
}

\author{
Tingting Yang1*, Min He ${ }^{1 *}$, Hailiang Zhang2,3, Paula Q Barrett ${ }^{4}$ and Changlong $\mathrm{Hu}^{1}$ \\ 1Department of Physiology and Biophysics, School of Life Sciences, Institutes of Brain Science, Fudan University, Shanghai, China \\ 2Department of Urology, Fudan University Shanghai Cancer Center, Shanghai Medical College, Fudan University, Shanghai, China \\ ${ }^{3}$ Department of Oncology, Shanghai Medical College, Fudan University, Shanghai, China \\ ${ }^{4}$ Department of Pharmacology, University of Virginia, Charlottesville, Virginia, USA
}

Correspondence should be addressed to H Zhang or C Hu: zhangh1918@163.com or clhu@fudan.edu.cn

*(T Yang and M He contributed equally to this work)

\begin{abstract}
Aldosterone, which plays a key role in the regulation of blood pressure, is produced by zona glomerulosa (ZG) cells of the adrenal cortex. Exaggerated overproduction of aldosterone from ZG cells causes primary hyperaldosteronism. In ZG cells, calcium entry through voltage-gated calcium channels plays a central role in the regulation of aldosterone secretion. Previous studies in animal adrenals and human adrenal adrenocortical cell lines suggest that the T-type but not the L-type calcium channel activity drives aldosterone production. However, recent clinical studies show that somatic mutations in L-type calcium channels are the second most prevalent cause of aldosterone-producing adenoma. Our objective was to define the roles of $\mathrm{T}$ and L-type calcium channels in regulating aldosterone secretion from human adrenals. We find that human adrenal ZG cells mainly express T-type $\mathrm{Ca}_{\mathrm{v}} 3.2 / 3.3$ and L-type $\mathrm{Ca}_{\mathrm{v}} 1.2 / 1.3$ calcium channels. TTA-P2, a specific inhibitor of T-type calcium channel subtypes, reduced basal aldosterone secretion from acutely prepared slices of human adrenals. Surprisingly, nifedipine, the prototypic inhibitor of L-type calcium channels, also decreased basal aldosterone secretion, suggesting that L-type calcium channels are active under basal conditions. In addition, TTA-P2 or nifedipine also inhibited aldosterone secretion stimulated by angiotensin II- or elevations in extracellular $\mathrm{K}^{+}$. Remarkably, blockade of either L- or T-type calcium channels inhibits basal and stimulated aldosterone production to a similar extent. Low concentrations of TTA-P2 and nifedipine showed additive inhibitory effect on aldosterone secretion. We conclude that T- and L-type calcium channels play equally important roles in controlling aldosterone production from human adrenals.
\end{abstract}

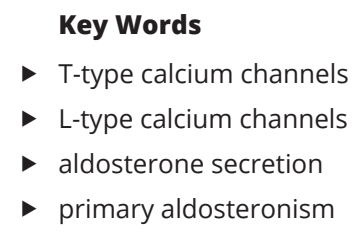

Journal of Endocrinology (2020) 244, 237-247

\section{Introduction}

Aldosterone, a steroid hormone produced by zona glomerulosa (ZG) cells of the adrenal cortex, plays a key role in maintaining electrolyte and water balance, and thereby the control of blood pressure. Primary aldosteronism (PA), caused by autonomous overproduction of aldosterone, is the most common form of secondary endocrine hypertension (Stowasser 2001). Approximately 10\% of hypertensive patients have PA (Rossi et al. 2006,

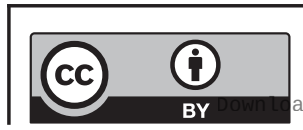

This work is licensed under a Creative Commons Attribution 4.0 International License. 
Rossi 2011, Hannemann \& Wallaschofski 2012), compared to $20 \%$ of individuals with resistant hypertension (Calhoun et al. 2002, Douma et al. 2008, Rossi 2011, Hannemann \& Wallaschofski 2012). Idiopathic hyperaldosteronism and aldosterone-producing adenoma are the two most common subtypes of PA (Funder et al. 2008, Monticone et al. 2017). Notably, somatic mutations of potassium and calcium channels have been found in more than half of aldosterone-producing adenomas (Yang et al. 2018).

Intracellular $\mathrm{Ca}^{2+}$ regulates key steps in aldosterone biosynthesis from ZG cells (Barrett et al. 2016). Calcium controls the early rate-limiting step, the conversion of cholesterol to pregnenolone, by stimulating the transfer of cholesterol to CYP11A1 on the inner mitochondrial membrane (Cherradi et al. 1996). Calcium controls the late rate-limiting step, the conversion of deoxycorticosterone to aldosterone, by stimulating the production of NADPH, a required cofactor for CYP11B2 activity (Lifton et al. 1992, Rossier et al. 1996a, Lalevee et al. 2003, Wiederkehr et al. 2011). In ZG cells, a rise of intracellular $\mathrm{Ca}^{2+}$ can be generated either by releasing $\mathrm{Ca}^{2+}$ from intracellular stores or by increasing extracellular $\mathrm{Ca}^{2+}$ entry through voltagegated calcium channels (Lotshaw 2001).

Extracellular $\mathrm{Ca}^{2+}$ entry through $\mathrm{ZG}$ voltage-gated calcium channels is necessary to maintain stimulated secretion induced by angiotensin II (Ang II) or $\mathrm{K}^{+}$, which are the two primary physiological aldosterone secretagogues in vivo (Barrett et al. 2016, Yang et al. 2018). ZG voltage-gated calcium channels are differentially expressed among mammalian species. Mainly two types of calcium currents have been identified in human, rat, mouse, and bovine ZG cells: high voltage-activated (L-type, including $\mathrm{Ca}_{\mathrm{V}}$ 1.1-1.4 subtypes) and low voltageactivated (T-type, including $\mathrm{Ca}_{\mathrm{V}}$ 3.1-3.3 subtypes) calcium channel currents (Cohen et al. 1988, Payet et al. 1994, Rossier et al. 1996b, Schrier et al. 2001, Hu et al. 2012). However, previous studies indicate that the activity of the T-type, but not that of the L-type channel, correlates with aldosterone secretion in dispersed preparations of animal ZG cells and human adrenocortical cell lines (Barrett et al. 1995, Rossier et al. 1996b, Imagawa et al. 2006, Akizuki et al. 2008). Thus, surprisingly recent clinical studies have found more than 25 different somatic $\mathrm{Ca}_{\mathrm{V}} 1.3 \mathrm{~L}$-type calcium channels mutations in patients with PA (Yang et al. 2018), suggesting that in humans L-type calcium channels may also play an equally important role in controlling aldosterone production.

In this study, we assessed the contribution of T- and L-type calcium channels to the control of basal and stimulated aldosterone production from human adrenal slices. We find that both channel types participate in the control of aldosterone production from human ZG cells that remained within adrenal tissue slices.

\section{Materials and methods}

\section{Cell culture and chemicals}

Human adrenocortical cell line, H295R (ATCC\#: CRL-2128), was purchased from American Type Culture Collection. Cells were cultured in Dulbecco's modified Eagle's medium: Nutrient Mixture F-12 medium (GIBCO) supplemented with 10\% fetal bovine serum (GIBCO), $1 \%$ antibiotic solution, and $0.1 \%$ insulin, transferrin and selenium premix (BD Biosciences). Human embryonic kidney cell line, HEK293, was purchased from The Cell Bank of Chinese Academy of Science. Cells were cultured in DMEM (Gibco) supplemented with 10\% fetal bovine serum and 1\% antibiotic antimycotic solution. TTA-P2 was purchased from Alomone Laboratories; Angiotensin II and nifedipine were purchased from Sigma-Aldrich.

\section{Aldosterone secretion of human adrenal gland}

Adrenal gland samples were obtained from 28 patients (16 men and 12 women, age $36-70$ years old) undergoing radical nephrectomy to remove kidney cancer and adjacent ipsilateral adrenal. The protocol for obtaining and using human adrenal tissues in this work was approved by the Ethics Committee of Shanghai Cancer Center (0504344-1212B) and School of Life Sciences (2017-601), Fudan University. Written informed consent from all patients was obtained. All protocols were in accordance with institutional guidelines.

Human adrenal samples were prepared as previously described (Yang et al. 2016). Briefly, human adrenal samples were transported in cold PBS, and then kept in ice-cold bicarbonate-buffered saline containing: $140 \mathrm{mmol} / \mathrm{L} \mathrm{NaCl}, 2 \mathrm{mmol} / \mathrm{L} \mathrm{KCl}, 0.1 \mathrm{mmol} / \mathrm{L} \mathrm{CaCl}$, $5 \mathrm{mmol} / \mathrm{L} \mathrm{MgCl}_{2}, 26 \mathrm{mmol} / \mathrm{L} \mathrm{NaHCO}_{3}$, and $10 \mathrm{mmol} / \mathrm{L}$ glucose, bubbled with $95 \% \mathrm{O}_{2}$ and $5 \% \mathrm{CO}_{2}$. Fat tissues around adrenal glands were removed. Tissues were embedded in 2.5\% low-melting temperature agarose (2-hydroxyethylagarose, Sigma-Aldrich) and sectioned into $300 \mu \mathrm{m}$ slices using DSK microslicer (DOSAKA). The slices were placed on Millicell-CM membranes (pore size $0.4 \mu \mathrm{m}$, Millipore) and incubated in Hanks MEM (Gibco) containing $1 \mathrm{mmol} / \mathrm{L}$ L-glutamine, $1 \mathrm{mmol} / \mathrm{L} \mathrm{CaCl}, 2 \mathrm{mmol} / \mathrm{L} \mathrm{MgCl}_{2}, 30 \mathrm{mmol} / \mathrm{L} \mathrm{HEPES}$, 
$12.8 \mathrm{mmol} / \mathrm{L}$ glucose, $5.24 \mathrm{mmol} / \mathrm{L} \mathrm{NaHCO}_{3}, 12 \mathrm{mg} / \mathrm{L}$ bovine insulin, $0.12 \%$ ascorbic acid, and $20 \%$ horse serum (Gibco) at $37^{\circ} \mathrm{C}$ with $5 \% \mathrm{CO}_{2}$. Because the steroid synthesis profile of $\mathrm{ZG}$ cells may change during primary culture (Williams et al. 2014), in this study, we conducted relatively short time course secretion experiments. Slices were incubated for $2 \mathrm{~h}$ to determine basal production (control), and then treated with the indicated agents for $6 \mathrm{~h}$ to evaluate stimulated production. Slice culture supernatants were collected before and after treatment. Supernatant aldosterone concentrations were measured by an Aldosterone ELISA Kit (ENZO Life Science) as previously reported (Yang et al. 2016). For $62.5 \mathrm{pg} / \mathrm{mL}$ and $125 \mathrm{pg} / \mathrm{mL}$ aldosterone, the intra-assay co-efficients of variation were 5.2 and 6.2, and the inter-assay co-efficients of variation were 11.7 and 7.9. A standard curve (ranging from $3.9 \mathrm{pg} / \mathrm{mL}$ to $500 \mathrm{pg} / \mathrm{mL}$ ) was conducted along with samples for every measurement. $10 \mu \mathrm{L}$ supernatant (1:10 dilution in assay buffer) was used for aldosterone ELISA assay. In this condition, the mean percent recovery for $150 \mathrm{pg} / \mathrm{mL}$ and $50 \mathrm{pg} / \mathrm{mL}$ aldosterone were 93 and 98\% respectively. Data were presented as fold over baseline to avoid ZG mass differences among the adrenal slices.

\section{Immunofluorescence}

Human adrenal glands were fixed in $4 \%$ paraformaldehyde at $4^{\circ} \mathrm{C}$ overnight, and transferred sequentially to 10,20 , and 30\% sucrose/PBS. Tissues were embedded by OCT, and placed at $-80^{\circ} \mathrm{C}$. Tissues were sectioned (Leica CM1950 cryostat) into $20 \mu \mathrm{m}$ slices and dried at room temperature. Slices were post-fixed in 4\% paraformaldehyde for $15 \mathrm{~min}$, washed (cold PBS), incubated in 0.5\% PBST for $10 \mathrm{~min}$, and blocked (10\% horse serum, $0.3 \%$ PBST) for $2 \mathrm{~h}$ at room temperature. Slices were then incubated in primary antibody solution (primary antibody (mouse anti-Ca $\mathrm{Ca}_{\mathrm{V}}$ 1.2: 1:200, AB11001554, Neuromab; mouse anti-Ca $\mathrm{Ca}_{\mathrm{V}} 1.3$ : 1:200, AB10673964, Neuromab; mouse anti-Ca $\mathrm{V}_{\mathrm{V}} 3.1$ : 1:200, AB2069421 Neuromab; rabbit anti-Ca $\mathrm{Ca}_{\mathrm{V}} 3.2: 1: 200$, \#ACC-025, Alomone; rabbit anti-Ca $\mathrm{V}_{\mathrm{V}} 3.3: 1: 200$, \#ACC-009, Alomone; rabbit anti-CYP11B2: 1:200, \#ab168388, Abcam), 1\% horse serum, and $0.3 \%$ PBST) for 1 day at $4^{\circ} \mathrm{C}$. Slices were washed with PBS, and incubated in secondary antibody solution [(secondary antibody (Cy3-labled goat anti-rabbit IgG or FITC-labeled goat anti-mouse IgG, 1:500, Beyotime), containing 1\% horse serum, and $0.3 \%$ PBST) at $4^{\circ} \mathrm{C}$ overnight. After washing with PBS, slices were treated with DAPI. Confocal images were obtained using a Leica SP2 confocal microscope.

\section{ZG cell isolation, RNA extraction and RT-PCR}

The ZG layer was isolated from human adrenal glands using laser capture microdissection (Arcturus XT system, Life Technologies). Before laser capture microdissection, adrenal glands were incubated in RNAlater Solution (Life Technologies) at $4^{\circ} \mathrm{C}$ overnight, embedded with OCT, sectioned into $20 \mu \mathrm{m}$ slices, and stained with HistoGene Staining Solution (Life Technologies). RNA was extracted (RNeasy Micro Kit, QIAGEN), reverse transcribed (SMARTSeq v4 Ultra Low Input RNA Kit, Clontech Laboratories). PCR was performed in $20 \mu \mathrm{L}$ reactions containing: $2 \mu \mathrm{L}$ of template, $0.4 \mu \mathrm{mol} / \mathrm{L}$ of each paired primer, and iQ SYBR Green Supermix (Bio-Rad). The thermocycling conditions were $95^{\circ} \mathrm{C}, 3 \mathrm{~min} ; 40$ cycles of $95^{\circ} \mathrm{C}, 15 \mathrm{~s} ; 58^{\circ} \mathrm{C}, 30 \mathrm{~s} ; 72^{\circ} \mathrm{C}$, $30 \mathrm{~s}$; and $72^{\circ} \mathrm{C}, 10 \mathrm{~min}$. Primers used in PCR: $\mathrm{Ca}_{\mathrm{V}} 1.1$ : forward 5' CAGCAC TACAAC CAGTCG GA, reverse 5' CTCCAC CCAGGC AATACA GTC; $\mathrm{Ca}_{\mathrm{V}}$ 1.2: forward 5' CCTTTC TGGTTT AGCTGT GGG AAG ATCT, reverse 5' AATGCA AAGAGT TACTGAT TCCCGT TTCAG; $\mathrm{Ca}_{\mathrm{V}}$ 1.3: forward 5' GCACTA CGA GCA GTCCAA GA, reverse 5' GCTGCC GATTAC GATGAG GG; $\mathrm{Ca}_{\mathrm{V}}$ 1.4: forward 5' ACGGTG GAGATG CTTCTC AAATTG TACG, reverse 5' GGTGAC CTTAAA GATCCT GAGGAG GC; $\mathrm{Ca}_{\mathrm{V}} 3.1$ : forward 5' GATCCT GACCCA GGAGGA CT, reverse 5' AAGAGC ACGTAG TTGCCGAA; $\mathrm{Ca}_{\mathrm{V}} 3.2$ : forward 5' CCTGGA GGAGAG CAACAAGG, reverse 5' GGTCTC CATCTC CACСТCCT; $\mathrm{Ca}_{\mathrm{V}} 3.3$ : forward 5' ACGCAT CTTTCT CACCGTGT, reverse 5' ATGGGC TTGAGG GAGGAGAT.

\section{Cell transfection and electrophysiology}

Plasmids for human $\mathrm{Ca}_{\mathrm{V}} 3.1, \mathrm{Ca}_{\mathrm{V}} 3.2$ and $\mathrm{Ca}_{\mathrm{V}} 3.3$ channels (as previously reported (Cui et al. 2014)) were transiently transfected in H295R or HEK293 cells using jetPRIME (Polyplus) according to the manufacturer's instruction. For electrophysiological experiments, cells were used $24 \mathrm{~h}$ after transfection. $\mathrm{Ca}_{\mathrm{V}} 1.2$ (Plasmid \# 26572, Addgene) (Helton et al. 2005) or $\mathrm{Ca}_{\mathrm{V}} 1.3$ (Plasmid \# 26576, Addgene) (Xu \& Lipscombe 2001) channels from Addgene (Cambridge, MA, USA) were transfected together with $\beta 2$ and $\alpha 2 \delta 1$ subunits (ratio 1:1:1) in H295R cells for 48-72 $\mathrm{h}$ before electrophysiological measurements. Whole-cell currents in the H295R cells were recorded using an Axopatch 200B amplifier (Axon Instruments). The bath solution contained (in mmol/L): $143 \mathrm{TEACl}, 10 \mathrm{CaCl}_{2}$ (for $\mathrm{Ca}_{\mathrm{V}} 3$ channel) or $\mathrm{BaCl}_{2}$ (for $\mathrm{Ca}_{\mathrm{V}} 1$ channel), $2 \mathrm{MgCl}_{2}, 10$ HEPES, and 10 Glucose, pH 7.4 (adjusted with TEAOH). The internal solution contained (in mmol/L): $125 \mathrm{CsCl}$, 10 HEPES, 10 EGTA, $1 \mathrm{MgCl}_{2}, 1 \mathrm{CaCl}_{2}, 5 \mathrm{Mg}$-ATP, and

This work is licensed under a Creative Commons Attribution 4.0 International License. ed from Bioscientifica.com at 04/26/2023 11:21:44AM via free access 
0.3 Tris-GTP (pH adjusted to 7.2 using $\mathrm{CsOH}$ ). Recording pipettes (capillary tubing, BRAND) had resistances of 4-6 M $\Omega$. All of the recordings were performed at room temperature. Currents were sampled at $10 \mathrm{kHz}$ and filtered at $2 \mathrm{kHz}$, and corrected online for leak and residual capacitance transients using a $\mathrm{P} / 4$ protocol.

\section{Data presentation and statistical analysis}

Data analysis was performed with Clampfit 10.2 (Axon Instruments) and Origin 8.0 (OriginLab). The normal distribution of the data was checked by the ShapiroWilk test. Statistical analysis was performed using paired Student $t$ tests unless indicated otherwise. The nonparametric Kruskal-Wallis test was used to compare groups that did not meet the assumption of normality. Values are given as means \pm s.e.m., $n$ indicated the number of tested cells, patient samples or independent tests. $P<0.05$ was considered statistically significant.

\section{Results}

\section{L- and T-type calcium channels regulate basal aldosterone production from human adrenal slices}

To determine which L-type calcium channel subtypes were expressed in human ZG cells, we isolated ZG cells by laser capture microdissection and tested for mRNA expression. As shown in Fig. 1A, mRNA for $\mathrm{Ca}_{\mathrm{V}} 1.2$ and $\mathrm{Ca}_{\mathrm{V}} 1.3$ but not $\mathrm{Ca}_{\mathrm{V}} 1.1$ and $\mathrm{Ca}_{\mathrm{V}} 1.4$ was detected in $\mathrm{ZG}$ cells. All PCR products were confirmed by sequencing. To corroborate protein expression of $\mathrm{Ca}_{\mathrm{V}} 1.2$ and $\mathrm{Ca}_{\mathrm{V}} 1.3$ channels we used immunofluorescence. Immunodetection showed high expression of both $\mathrm{Ca}_{\mathrm{V}} 1.2$ and $\mathrm{Ca}_{\mathrm{V}} 1.3$ channel protein in the ZG layer of the human adrenal (Fig. 1B). By contrast, although the mRNA for all three T-type calcium channel subtypes was detected in ZG cells (Fig. 2A), the expression of T-type calcium channel protein, as reported by immunofluorescence, showed only strong expression for $\mathrm{Ca}_{\mathrm{V}} 3.2$ and $\mathrm{Ca}_{\mathrm{V}} 3.3$ channel protein. Signals for $\mathrm{Ca}_{\mathrm{V}} 3.1$ channels were not detected (Fig. 2B, C and D) in the ZG layer of the human adrenal cortex, indicating a discrepancy between mRNA and protein expression. To assess the selectivity of these antibodies, and thus verify our putative expression findings, HEK293 cells were transfected with a vector encoding one of five channel subtypes to provide both positive and negative immunodetection controls. HEK293 cells expressing $\mathrm{Ca}_{\mathrm{V}} 3.1, \mathrm{Ca}_{\mathrm{V}} 3.2, \mathrm{Ca}_{\mathrm{V}} 3.3, \mathrm{Ca}_{\mathrm{V}} 1.2$ and $\mathrm{Ca}_{\mathrm{V}} 1.3$ channels showed strong immunofluorescence signals only with antibodies against their own antigenic target; no signals were detected in either un-transfected HEK293 cells or in cells transfected with other channel family members (Supplementary Figs 1 and 2, see section on supplementary materials given at the end of this article). Thus, the normal human adrenal cortex, indeed expresses proteins for both $\mathrm{Ca}_{\mathrm{V}} 1 . \mathrm{x}$ and $\mathrm{Ca}_{\mathrm{V}} 3 . \mathrm{x}$ channels.

Next, we used the L-type calcium channel-specific inhibitor, nifedipine and the T-type calcium channelspecific inhibitor, TTA-P2, to test the contribution of each channel class to basal aldosterone secretion from human
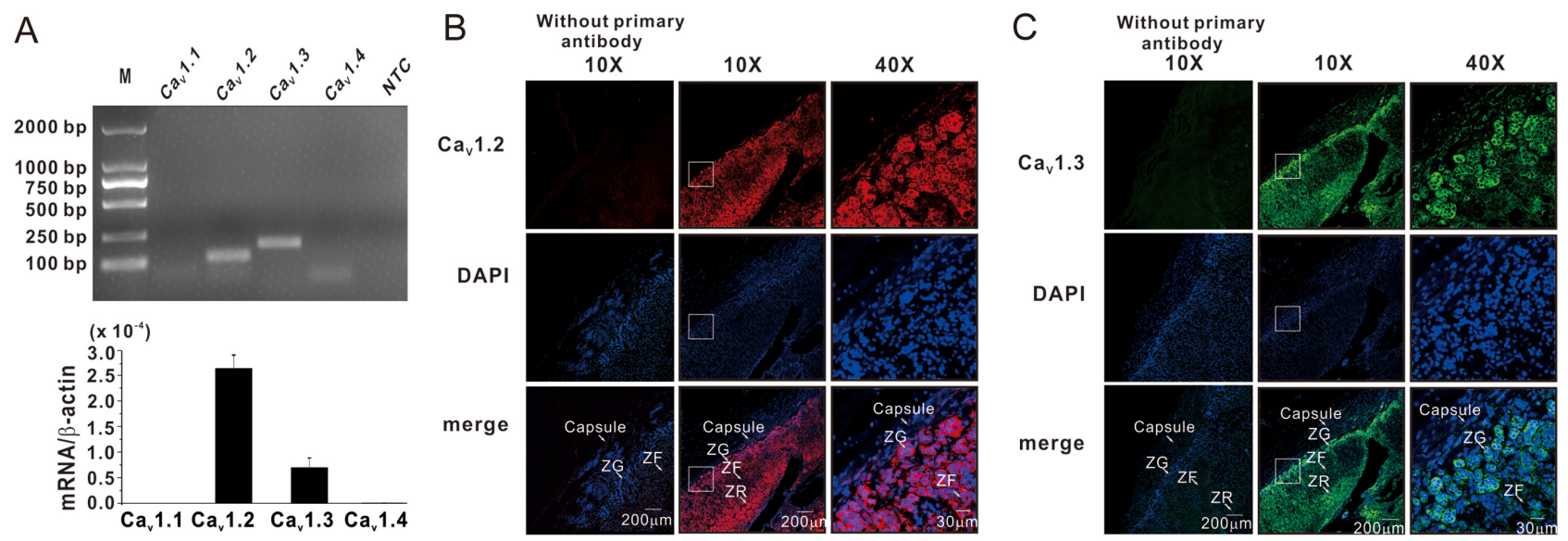

\section{Figure 1}

L-type calcium channel expression in the zona glomerulosa of human adrenals. (A) Human ZG cells express mRNA for L-type calcium channels. Zona glomerulosa was isolated using laser capture microdissection. Real-time PCR revealed message for L-type Ca2+ channels (Ca 1.2 and Ca 1.3 , but not $\mathrm{Ca}_{\mathrm{v}} 1.1$ and $\left.\mathrm{Ca}_{\mathrm{v}} 1.4\right)$. ( $\mathrm{B}$ and $\left.\mathrm{C}\right)$ Representative examples of immunofluorescence images showing high expression of $\mathrm{Ca}_{\mathrm{v}} 1.2$ and $\mathrm{C} \mathrm{a}_{\mathrm{V}} 1.3 \mathrm{channels}$ in zona glomerulosa of the human adrenal cortex. Zona fasciculata (ZF). zona reticularis (ZR).

https://joe.bioscientifica.com https://doi.org/10.1530/JOE-19-0259 (c) 2020 The authors Published by Bioscientifica Ltd. Printed in Great Britain

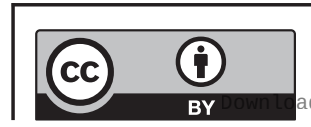

This work is licensed under a Creative Commons Attribution 4.0 International License. ed from Bioscientifica.com at 04/26/2023 11:21:44AM 

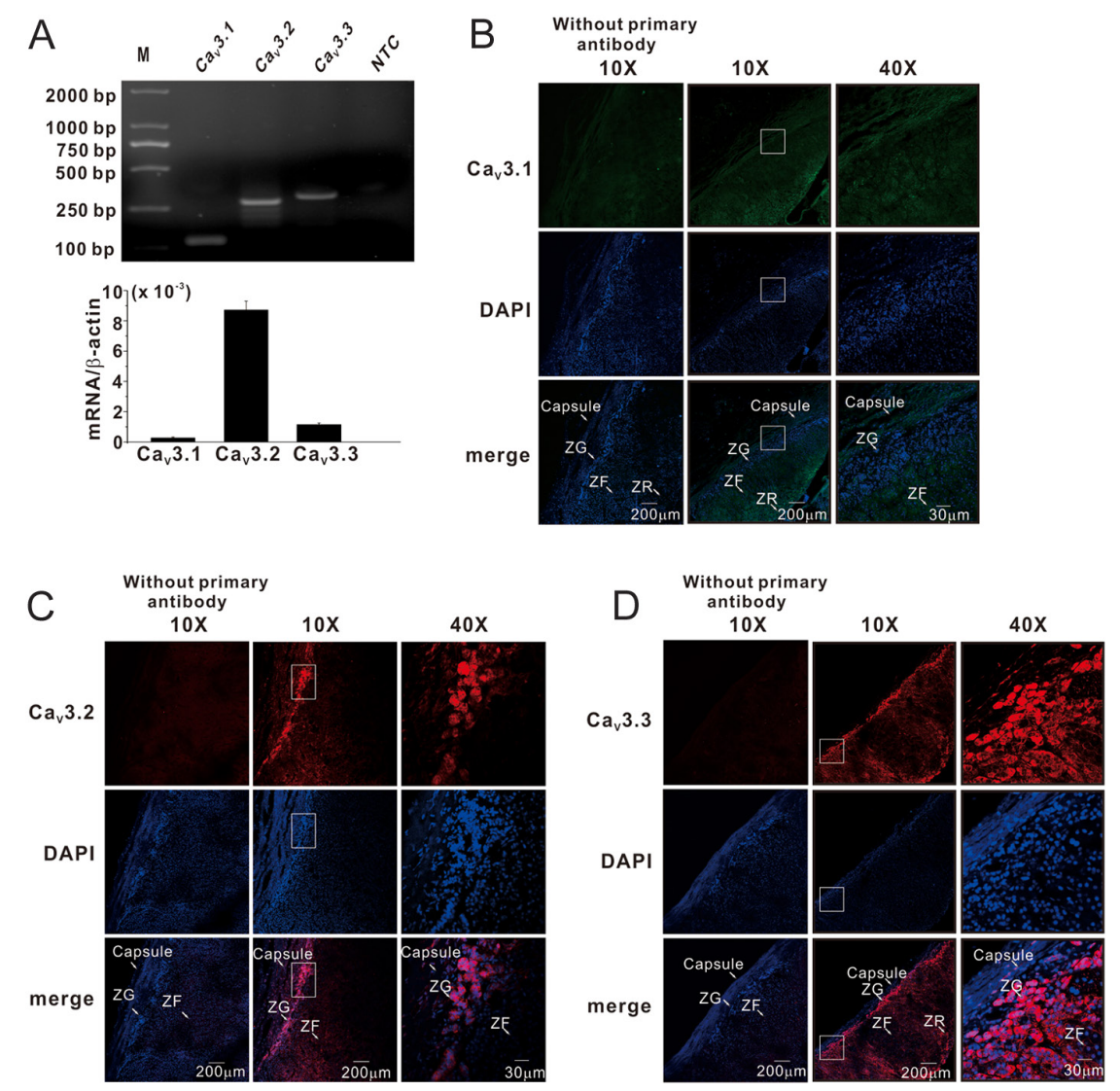

\begin{abstract}
Figure 2
T-type calcium channel expression in the zona glomerulosa of human adrenals. (A) Human ZG cells express mRNA for T-type calcium channels. Zona glomerulosa was isolated using laser capture microdissection. Real-time PCR revealed message for T-type Ca2+ channels ( $\mathrm{Ca}_{\mathrm{v}} 3.1, \mathrm{Ca}_{\mathrm{v}} 3.2$ and $\mathrm{Ca}_{\mathrm{v}}$ 3.3). (B, C and D) Representative examples of immunofluorescence images showing high expression of $\mathrm{Ca}_{\mathrm{v}} 3.2$ and $\mathrm{Ca}_{\mathrm{v}} 3.3$ but not $\mathrm{Ca}_{\mathrm{v}} 3.1$ channels in zona glomerulosa of the human adrenal cortex.
\end{abstract}

adrenal slices. $500 \mathrm{nmol} / \mathrm{L}$ nifedipine significantly and consistently reduced aldosterone secretion from adrenal tissue slices prepared from ten individual patient adrenals (percent inhibition: $46 \pm 6 \%, n=10, P<0.01$ compared with control by Student $t$ tests, Fig. 3A). $2 \mu \mathrm{mol} / \mathrm{L}$ TTA-P2 also significantly inhibited aldosterone secretion from adrenal tissue slices prepared from 11 individual patient adrenals (percent inhibition: $44 \pm 5 \%, n=11, P<0.01$, Fig. 3B).

Although nifedipine is considered to be a highly selective L-type calcium channels blocker (Stengel et al. 1998), we tested if nifedipine could also partially inhibit T-type calcium channels at high nanomolar concentration. Because human adrenal ZG cells express both $\mathrm{Ca}_{\mathrm{V}} 3.2$ and $\mathrm{Ca}_{\mathrm{V}} 3.3$ channels, we evaluated the inhibition of $\mathrm{Ca}_{\mathrm{V}} 3.2$ and $\mathrm{Ca}_{\mathrm{V}} 3.3$ currents in $\mathrm{H} 295 \mathrm{R}$ cells by $500 \mathrm{nmol} / \mathrm{L}$ nifedipine. Calcium currents were elicited by a 50-ms depolarizing pulse to $-20 \mathrm{mV}$ from a holding potential of $-90 \mathrm{mV}$ at $10 \mathrm{~s}$ intervals. $500 \mathrm{nmol} / \mathrm{L}$ nifedipine did not inhibit either $\mathrm{Ca}_{\mathrm{V}} 3.2$ or $\mathrm{Ca}_{\mathrm{V}} 3.3$ channel currents, whereas $2 \mu \mathrm{mol} / \mathrm{L}$ TTA-P2 fully inhibited the currents (Fig. 4A and $\mathrm{B}, n=5-6)$. To confirm the efficacy of nitrendipine, we tested its effects on $\mathrm{Ca}_{\mathrm{V}} 1.2$ and $\mathrm{Ca}_{\mathrm{V}} 1.3$ channel currents at $500 \mathrm{nmol} / \mathrm{L}$. As shown in Fig. 4C and D, $500 \mathrm{nmol} / \mathrm{L}$ nifedipine almost fully inhibited $\mathrm{Ca}_{\mathrm{V}} 1.2$ and
$\mathrm{Ca}_{\mathrm{V}} 1.3$ channel currents in $\mathrm{H} 295 \mathrm{R}$ cells, in contrast to $2 \mu \mathrm{mol} / \mathrm{L}$ TTA-P2 which had little effect $(n=5)$. To rule out a nonselective inhibitory effect of these drugs at voltages other than $-20 \mathrm{mV}$, we recorded the current-voltage relationship for each channel $\left(\mathrm{Ca}_{\mathrm{V}} 1.2,1.3,3.2,3.3\right)$ and tested for drug-induced changes. At all voltages, $500 \mathrm{nmol} / \mathrm{L}$ nifedipine or $2 \mu \mathrm{mol} / \mathrm{L}$ TTA-P2 remained selective for their channel targets (Supplementary Fig. 3). The data above indicate that the inhibition of L- or T-type calcium channel activity should account for the induced effects of $500 \mathrm{nmol} / \mathrm{L}$ nifedipine or $2 \mu \mathrm{mol} / \mathrm{L}$ TTA-P2 reported here.

\section{Effect of nifedipine and TTA-P2 on Ang II- and $\mathrm{K}^{+}$-induced aldosterone secretion from human adrenal slices}

To assess the overall importance of L-type and T-type calcium channels in the production of aldosterone in human adrenals, we tested for nifedipine or TTA-P2 evoked modulation of Ang II- or $\mathrm{K}^{+}$-induced aldosterone secretion. As shown in Fig. 5A, $500 \mathrm{nmol} / \mathrm{L}$ nifedipine abrogated the stimulation of aldosterone production by $10 \mathrm{nmol} / \mathrm{L}$ Ang II (fold increase: Ang II, 2.4 \pm 0.6 ; Ang II + nifedipine, $0.9 \pm 0.1, n=6, P<0.05$ compared with 

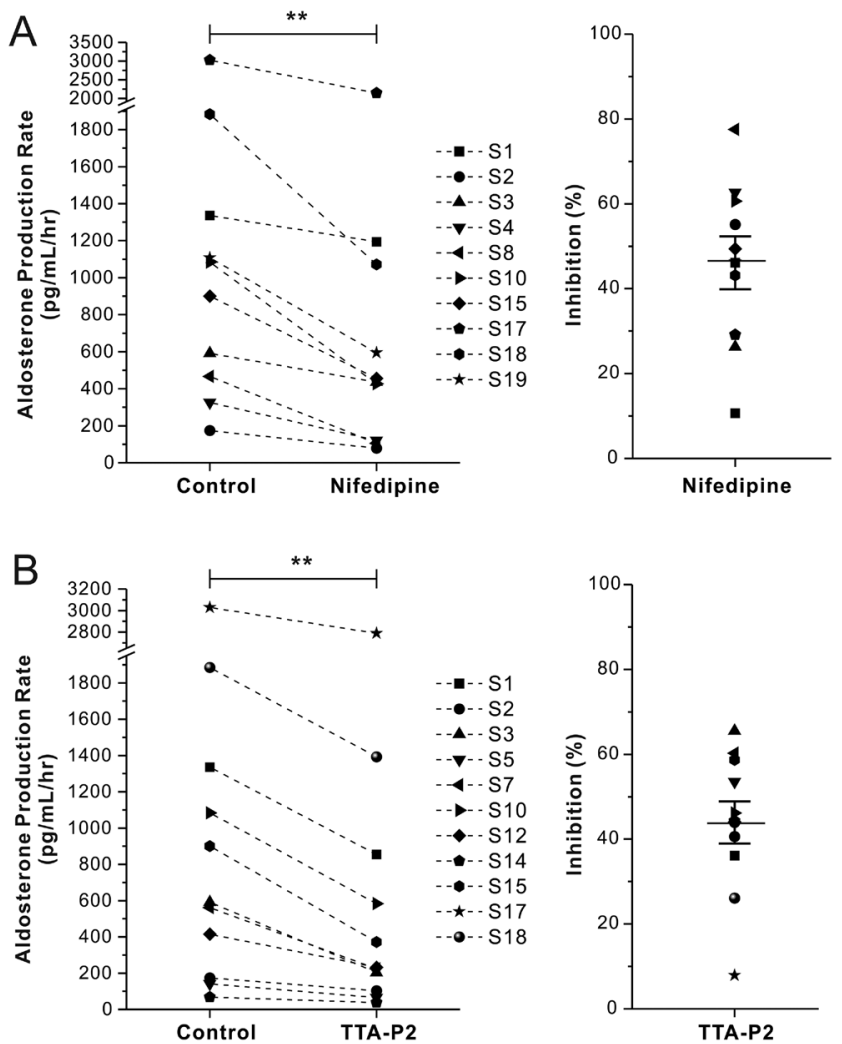

Figure 3

Effects of $\mathrm{L}$ - and $\mathrm{T}$-type calcium channels on basal aldosterone secretion from human adrenal slices. (A) Specific L-type channel blocker, nifedipine $(500 \mathrm{nmol} / \mathrm{L})$, inhibits basal aldosterone production from human adrenal slices (left); Statistical analysis of nifedipine induced inhibition of aldosterone secretion from human adrenal slices (right). Data expressed as fold over control. $* * P<0.01$ compared with control $(n=10)$. (B) Specific T-type channel blocker TTA-P2 ( $2 \mu \mathrm{mol} / \mathrm{L})$ reduced basal aldosterone production from human adrenal slices (left); Statistical analysis of TTA-P2-induced inhibition of aldosterone secretion from human adrenal slices (right). ${ }^{*} P<0.01$ compared with control $(n=11)$. (S1-19= samples from different individual patients.)

Ang II alone, Fig. 5B). $500 \mathrm{nmol} / \mathrm{L}$ nifedipine also abolished aldosterone production induced by High $\mathrm{K}^{+}(15 \mathrm{mmol} / \mathrm{L})$ (fold increase: High $\mathrm{K}^{+}, 2.4 \pm 0.4$; High $\mathrm{K}^{+}+$Nifedipine, $1.0 \pm 0.2, n=6, P<0.05$ compared with High $\mathrm{K}^{+}$alone, Fig. $5 \mathrm{C}$ and D). Interestingly, $2 \mu \mathrm{mol} / \mathrm{L}$ TTA-P2 also abrogated the stimulation of aldosterone production by Ang II or High $\mathrm{K}^{+}$from acutely prepared slices of human adrenals $(P<0.05$, Fig. 6). Together, these data indicate that in human adrenals both $\mathrm{T}$ - and L-type calcium channel activity is required for stimulated aldosterone synthesis.

\section{Additivity of effects of nifedipine and TTA-P2 on aldosterone production from human adrenal slices}

Finally, we tested whether the combined application of nifedipine and TTA-P2 could reduce aldosterone secretion
A
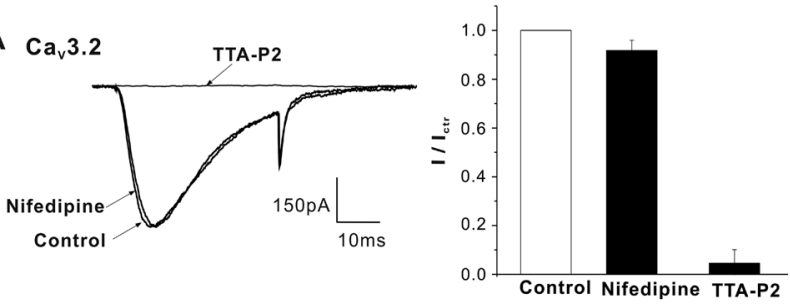

B
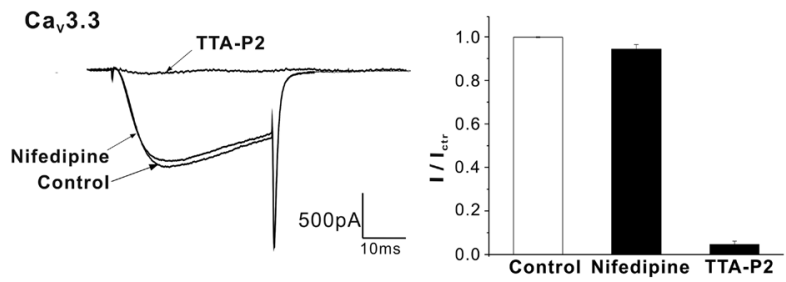

C
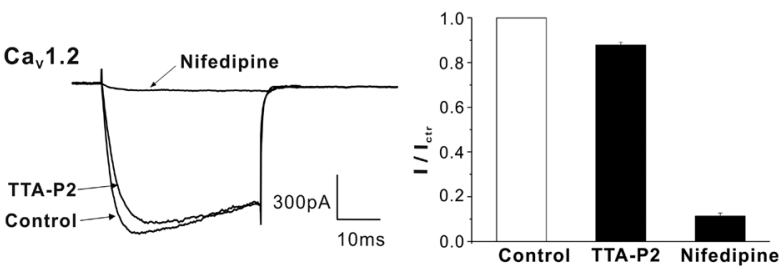

D
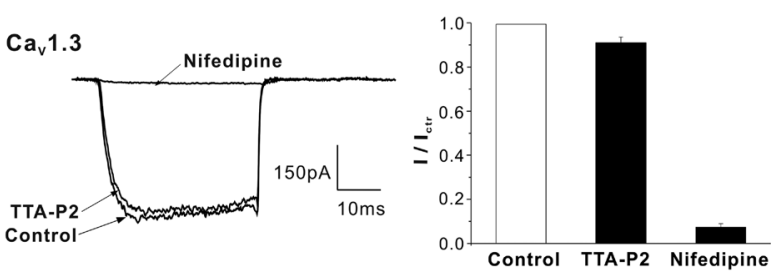

\section{Figure 4}

Effects of nifedipine $(500 \mathrm{nmol} / \mathrm{L})$ or TTA-P2 $(2 \mu \mathrm{mol} / \mathrm{L})$ on Ca $3.2 / 3$ and $\mathrm{Ca}_{\mathrm{v}} 1.2 / 3$ channel currents in H295R cells. (A) Effects of L-type Ca ${ }^{2+}$ channel inhibitor nifedipine and T-type $\mathrm{Ca}^{2+}$ channel inhibitor TTA-P2 on $\mathrm{Ca}_{\mathrm{v}} 3.2$ channel currents $(n=6)$. (B) Effects of $500 \mathrm{nmol} / \mathrm{L}$ nifedipine and $2 \mu \mathrm{mol} / \mathrm{L}$ TTA-P2 on Ca 3.3 channel currents $(n=5)$. (C) Effects of $500 \mathrm{nmol} / \mathrm{L}$ nifedipine and $2 \mu \mathrm{mol} / \mathrm{L}$ TTA-P2 on $\mathrm{Ca}_{\vee} 1.2$ channel currents $(n=5)$. (D) Effects of $500 \mathrm{nmol} / \mathrm{L}$ nifedipine and $2 \mu \mathrm{mol} / \mathrm{L}$ TTA-P2 on $\mathrm{Ca}_{\mathrm{V}} 1.3$ channel currents $(n=5)$. Calcium currents were elicited by a 50 -ms depolarizing pulse to $-20 \mathrm{mV}$ from a holding potential of $-90 \mathrm{mV}$ at $10 \mathrm{~s}$ intervals.

from human adrenal slices further than the level of inhibition induced by either drug alone. As shown in Fig. 7A, $2 \mu \mathrm{mol} / \mathrm{L}$ TTA-P2 did not augment the degree of inhibition induced by nifedipine $(P>0.05$ compared with nifedipine alone). Similarly, $500 \mathrm{nmol} / \mathrm{L}$ nifedipine did not increase the inhibition of basal aldosterone production from human adrenal slices produced by TTA-P2 $(n=5$, $P>0.05$ compared with TTA-P2 alone, Fig. 7B). To further test for drug additivity, we used lower concentrations of each antagonist, near the $\mathrm{IC}_{50}$ for $\mathrm{T}$ or $\mathrm{L}$ channel current inhibition (Fig. 7C). As shown in Fig. 7D, the inhibition of basal aldosterone secretion from human adrenal slices by $200 \mathrm{nmol} / \mathrm{L}$ TTA-P2 was additive to that of $100 \mathrm{~nm} / \mathrm{L}$ 

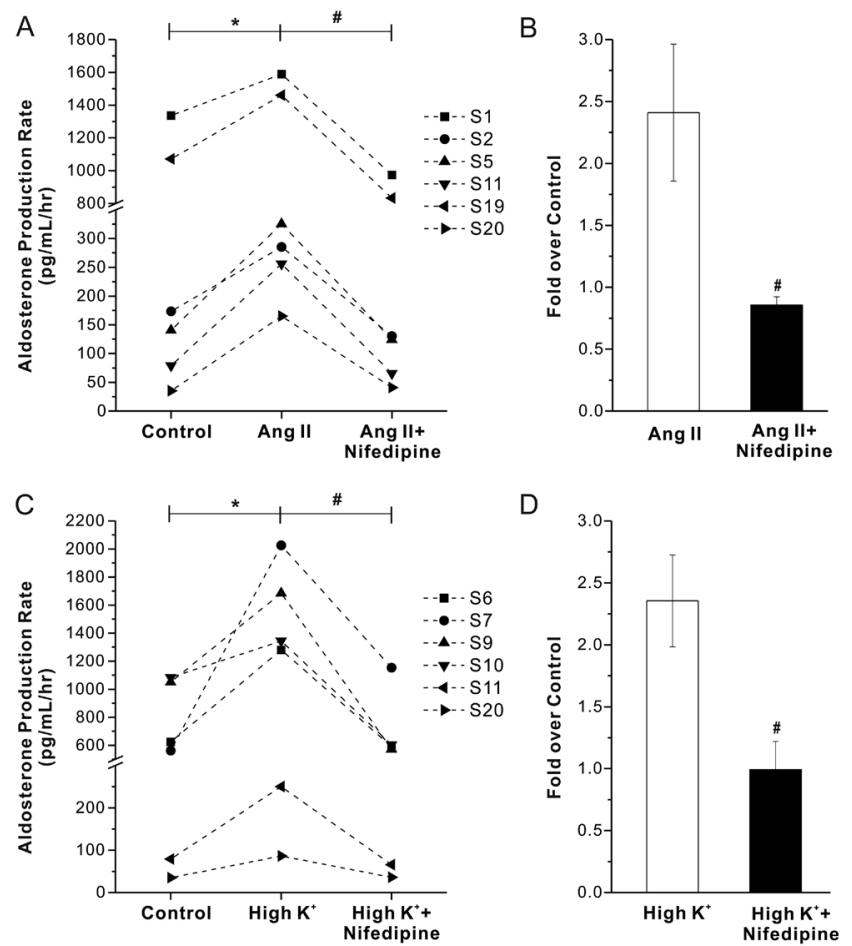

Figure 5

Effects of nifedipine on Angiotensin II (Ang II) - or high $\mathrm{K}^{+}$-stimulated aldosterone secretion from human adrenal slices. (A) Nifedipine abrogates Ang II-stimulated aldosterone secretion from human adrenal slices. (B) Statistical analysis of effect of nifedipine-induced inhibition of Ang II-stimulated aldosterone secretion. Data are presented as fold over control. ${ }^{*} P<0.05$ compared with control $(n=6)$. $\# P<0.05$ compared with Ang II alone $(n=6)$. (C) Nifedipine abrogated high $\mathrm{K}^{+}$-stimulated aldosterone secretion from human adrenal slices. (D) Statistical analysis of nifedipine-induced inhibition of high $\mathrm{K}^{+}$-stimulated aldosterone secretion. Data are presented as fold over control. $* P<0.05$ compared with control $(n=6) . \# P<0.05$ compared with high $\mathrm{K}^{+}$alone $(n=6)$.

nifedipine $(n=3)$. Drug additivity was also demonstrable against agonist-stimulated secretion. The inhibition of Ang II $(10 \mathrm{nmol} / \mathrm{L})$ or high $\mathrm{K}^{+}(15 \mathrm{mM})$-stimulated aldosterone secretion from human adrenal slices induced by either TTA-P2 (200 nmol/L) or nifedipine $(100 \mathrm{~nm} / \mathrm{L})$ was less than that effected by these channel antagonists in combination (Fig. 8). These data indicate that both Tand L-type calcium channels maybe necessary to drive aldosterone production.

With aging, the cellular capacity to synthesize aldosterone declines (Hegstad et al. 1983, Nanba et al. 2018). Less aldosterone synthase (CYP11B2) is expressed in the human ZG and more is expressed in aldosteroneproducing clusters (APCCs) found beneath the adrenal capsule (Nishimoto et al. 2010, 2016). APCCs, formed by non-neoplastic cells, increase with age and harbor mutations in the CACNA1D gene that encodes $\mathrm{Ca}_{\mathrm{V}} 1.3$ channels (Nishimoto et al. 2015, Nanba et al. 2017).
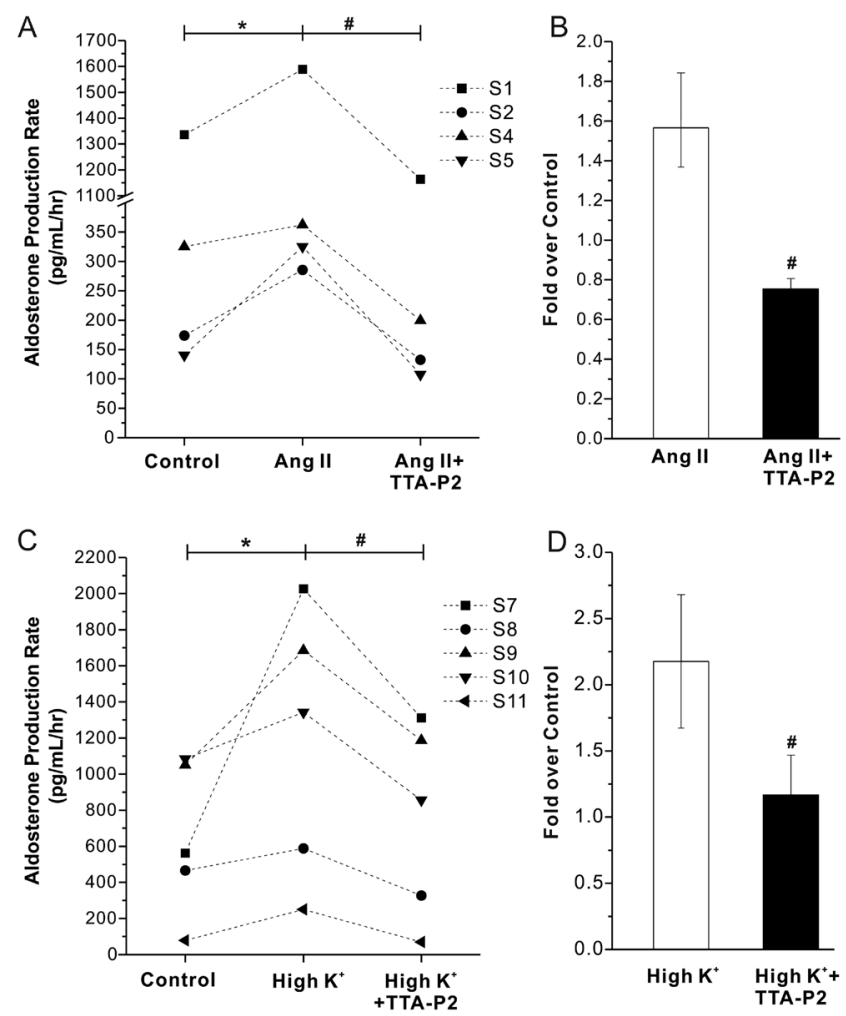

\section{Figure 6}

Effect of TTA-P2 on Angiotensin II (Ang II) - or high $\mathrm{K}^{+}$- stimulated aldosterone secretion from human adrenal slices. (A) TTA-P2 abrogates Ang II-stimulated aldosterone secretion from human adrenal slices. (B) Statistical analysis of TTA-P2 induced inhibition of Ang II-stimulated aldosterone secretion. Data are presented as fold over control. ${ }^{*} P<0.05$ compared with control. $\# P<0.05$ compared with Ang II alone $(n=4)$. (C) TTA-P2 abrogates high $\mathrm{K}^{+}$-stimulated aldosterone secretion from human adrenal slices. (D) Statistical analysis of TTA-P2 induced inhibition of high $\mathrm{K}^{+}$-stimulated aldosterone secretion. ${ }^{*} P<0.05$ compared with control. $\# P<0.05$ compared with high $\mathrm{K}^{+}$alone $(n=5)$.

Therefore, we calculated the size effect (percent inhibition by nifedipine) as a function of patient age to determine if the nifedipine-induced inhibition of aldosterone production reported here increased with patient age. In the relatively small sample size of our study, we found no significant correlations with aging suggesting a role for normal human L-type calcium channels in the control of aldosterone synthesis (basal production: $R=-0.21 ; P=0.56$ (Supplementary Fig. 4); Ang II stimulated: $R=0.23 ; P=0.66$ (data not shown); K-stimulated: $R=0.24 ; P=0.64$ (data not shown)).

\section{Discussion}

Here, we report the novel findings that in human adrenal glomerulosa cells both basal and stimulated rates of aldosterone production depend on voltage-gated

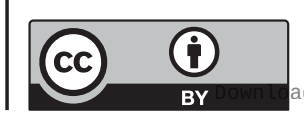

This work is licensed under a Creative Commons Attribution 4.0 International License. 

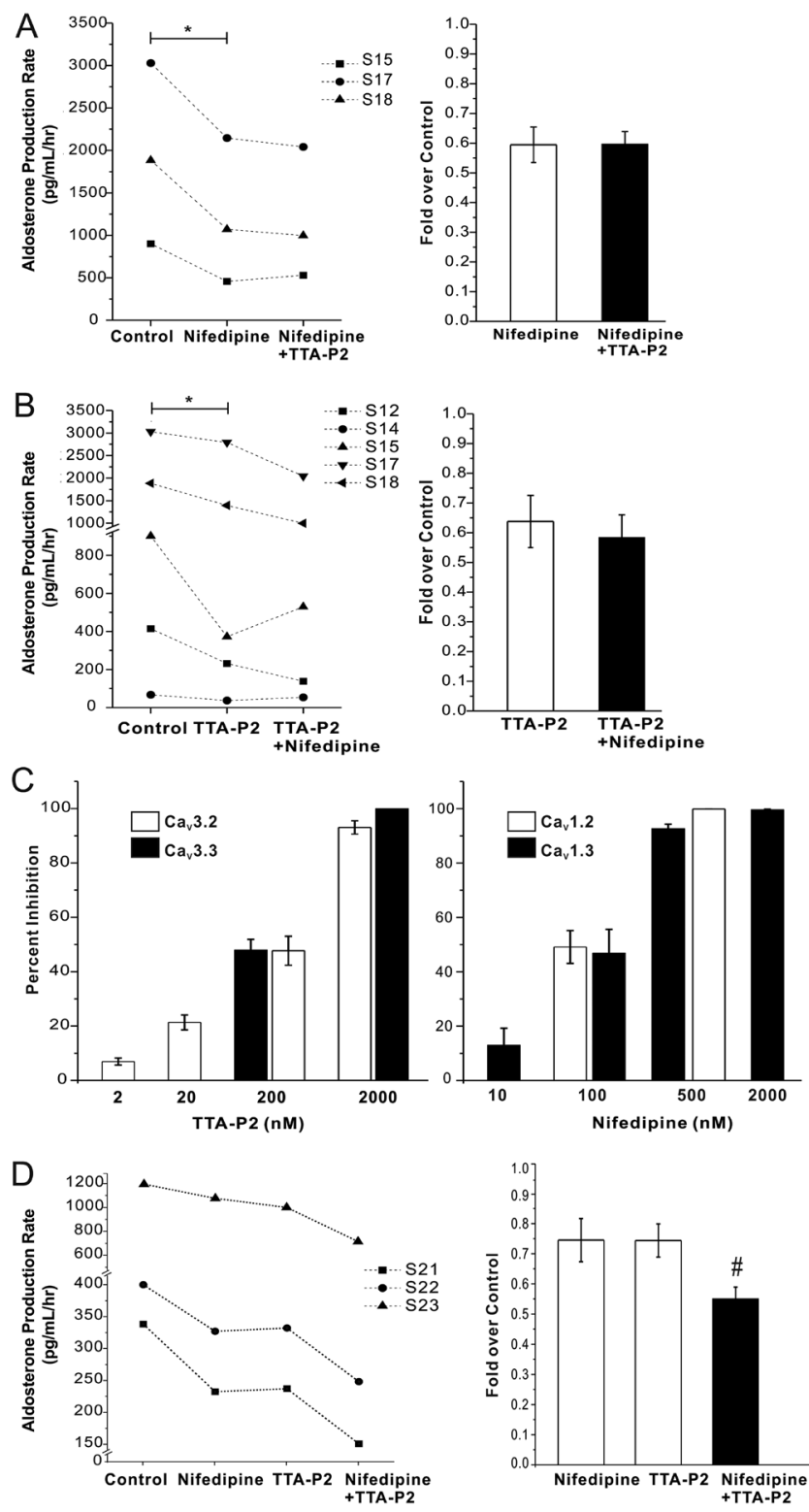

Figure 7

Effect of combined exposure to nifedipine and TTA-P2 on the basal production of aldosterone from human adrenal slices. Both nifedipine and TTA-P2 maximally inhibit aldosterone secretion. (A) TTA-P2 does not alter nifedipine-induced inhibition of aldosterone production from human adrenal slices. (B) Nifedipine does not alter TTA-P2 inhibition of aldosterone production from human adrenal slices $(n=5)$. (C) Effects of different concentrations of nifedipine or TTA-P2 on $\mathrm{Ca}_{\mathrm{V}} 3.2 / 3$ and $\mathrm{Ca}_{\mathrm{V}} 1.2 / 3$ channel currents in H295R cells. (D) $100 \mathrm{~nm} / \mathrm{L}$ nifedipine and $200 \mathrm{~nm} / \mathrm{L}$ TTA-P2 showed additive effect on basal aldosterone secretion. $\# P<0.05$ compared with nifedipine or TTA-P2 alone.

calcium currents through T-type as well as L-type calcium channels. These findings are surprising because patchclamp studies consistently report the basal membrane potential of ZG cells to be very hyperpolarized (around $-80 \mathrm{mV})$, a potential at which high threshold L-type
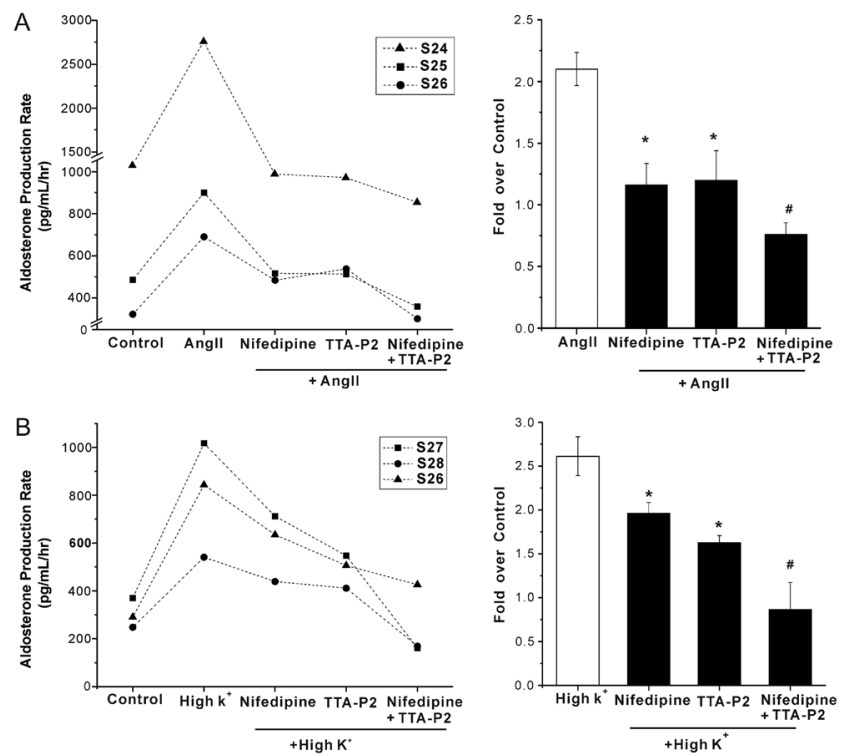

Figure 8

Effect of combined exposure to nifedipine and TTA-P2 on Ang II or high $\mathrm{K}^{+}$-stimulated aldosterone secretion from human adrenal slices. (A) 100 $\mathrm{nm} / \mathrm{L}$ nifedipine and $200 \mathrm{~nm} / \mathrm{L}$ TTA-P2 showed additive inhibitory effect on Ang II-stimulated aldosterone secretion from human adrenal slices. $\# P<0.05$ compared with nifedipine or TTA-P2 alone. (B) $100 \mathrm{~nm} / \mathrm{L}$ nifedipine and $200 \mathrm{~nm} / \mathrm{L}$ TTA-P2 showed additive inhibitory effect on high $\mathrm{K}^{+}$-stimulated aldosterone secretion. ${ }^{\#} P<0.05$ compared with nifedipine or TTA-P2 alone.

calcium channels are not expected to be active. In contrast, low threshold T-type calcium channels are activated at more hyperpolarized potentials and have a permissive window of steady-state activity at more hyperpolarized potentials (Perez-Reyes 2003). When stimulated by low physiological concentrations of Ang II or small increases in extracellular potassium, the membrane potential of ZG cells can rapidly reach the permissive voltage window for persistent T-type, but not L-type, calcium channel activity, that allows steady-state calcium influx (Rossier 2016). Therefore, in primary cultured ZG cells (Python et al. 1993, Rossier et al. 1993, 1996b, 1998, Lotshaw 2001) or H295R cells (Akizuki et al. 2008), it is not surprising that Ang II- or $\mathrm{K}^{+}$-stimulated aldosterone secretion consistently has been reported to be efficiently inhibited by various T-type calcium channel blockers, and not inhibited by highly selective L-type calcium channel inhibitors such as nifedipine. Nevertheless, previously we reported that mouse ZG cells when retained within an adrenal slice spontaneously generate Vm oscillations (Hu et al. 2012), of high amplitude, which can reach depolarized membrane voltages close to but always below $0 \mathrm{mV}$, voltages at which L-type calcium channels are active. Therefore, the contribution of L-type calcium channels to the regulation 
of aldosterone production previously may have been underestimated in studies of dispersed ZG cells that have lost the intrinsic ability to oscillate persistently.

Indeed, here we find that within human adrenal slices the L-type-specific blocker nifedipine significantly inhibited secretagogue-stimulated aldosterone secretion from ZG cells. Although some dihydropyridines that are considered to be specific L-type channel inhibitors, such as nicardipine and niguldipine also inhibit T-type calcium channels, nifedipine discriminates between T- and L-type calcium channel families (Stengel et al. 1998). Nifedipine selectively inhibits L-type calcium channels in human adrenocortical H295R cells (Rossier et al. 1996b, Imagawa et al. 2006, Akizuki et al. 2008, Yang et al. 2016) and in primary cultured human adrenal glomerulosa cells (Payet et al. 1994), and at $500 \mathrm{nM}$ in our study had no effect on recombinant $\mathrm{Ca}_{\mathrm{V}} 3.2$ and $\mathrm{Ca}_{\mathrm{V}} 3.3$ channel currents expressed in human adrenal cells. Therefore, inhibition of L-type calcium channel activity should account for the nifedipine-induced reduction of aldosterone production reported here. Similar to previous studies (Dreyfus et al. 2010, Enyeart \& Enyeart 2015), $2 \mu \mathrm{m}$ TTAP2 fully inhibits T-type calcium channels and has no effect on L-type calcium channels.

That nifedipine also inhibited aldosterone secretion from unstimulated human adrenal slices implies that L-type calcium channels are active even under basal condition. Again, we hypothesize that if human ZG cells within adrenal slices spontaneously generate $\mathrm{Vm}$ oscillations, as mouse ZG cells, this would enable L-type calcium channels to participate in regulating basal production. The direct proof of this prediction requires voltage recordings of human ZG cells by patch clamp. However, unfortunately we found that obtaining a gigaseal on adult human ZG cells (data not shown) was not possible. Rather, we used the very limited human adrenal samples for aldosterone secretion experiments. It is surprising that the degree of inhibition of aldosterone secretion evoked by nifedipine was equivalent to that of TTA-P2. At concentrations that produced maximal inhibition of L or T channel currents, no additivity of drug effects or synergy was observed, whereas at near half-maximal concentrations, nifedipine and TTA-P2 showed additive inhibitory effects on both basal and agonist-stimulated aldosterone secretion. Together, these observations suggest that in the human ZG layer, L- and T-type calcium channel flux may not be redundant but rather may each subserve a unique function that is required for the control of aldosterone production. Therefore, we propose a model for the regulation of aldosterone secretion from human
ZG cells by T- and L-type channels that can explain our findings. We predict that like mouse ZG cells, human ZG cells may also spontaneously oscillate, allowing the unique biophysical properties of each channel class to have distinct roles in controlling the oscillatory cycle. We hypothesize that by opening at more hyperpolarized potentials T-type channels may be principally responsible for recruiting L-type channels that, in turn, may provide the major calcium source of calcium required for the production of aldosterone; AngII or high $\mathrm{K}^{+}$may increase oscillation frequency and thus control the magnitude of calcium entry and the production of aldosterone.

The samples used in this study were obtained from patients spanning a broad age range and would be expected to contain an age-dependent increase in APCCs. Indeed, with tissue remaining from some patient samples, we detected a very large CYP11B2 expressing APCCs in one of three samples (Supplementary Fig. 5). Approximately onethird of APCCs (Nishimoto et al. 2015) harbor mutations in $\mathrm{Ca}_{\mathrm{V}} 1.3$ channels that lower the voltage dependence for channel activation or reduce channel inactivation (Azizan et al. 2013, Scholl et al. 2013), biophysical alterations that would make mutant channels more likely to participate in regulating calcium at hyperpolarized potentials. If mutant channels were the sole target of nifedipine action reported here, we would have expected an age-dependent increase in the efficacy of nifedipine, which we did not observe (Supplementary Fig. 4). Thus, we conclude that normal $\mathrm{Ca}_{\mathrm{V}} 1.3$ channels as well as mutant $\mathrm{Ca}_{\mathrm{V}} 1.3$ channels participated in the response to nifedipine. The relative contribution of each channel type to the inhibition of aldosterone synthesis induced by nifedipine in normal adrenal tissue is worthy of a future expanded study with a larger sample size.

In conclusion, our data demonstrate that L-type calcium channels play an important role in the regulation of aldosterone production from human ZG cells within a tissue context and that both T- and L-type calcium channels critically contribute to aldosterone production from human adrenals.

Supplementary materials

This is linked to the online version of the paper at https://doi.org/10.1530/ JOE-19-0259.

\section{Declaration of interest}

The authors declare that there is no conflict of interest that could be perceived as prejudicing the impartiality of the research reported.

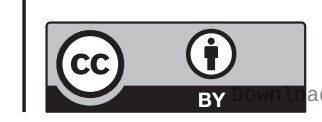

This work is licensed under a Creative Commons Attribution 4.0 International License. 


\section{Funding}

This work was supported by the National Natural Science Foundation of China (NSFC 31771282 and 31271240) and the National Key R\&D Program of China (2016YFA0100802) awarded to $\mathrm{CH}$, and by grant from the National Institutes of Health (HL138241) awarded to P Q B.

\section{References}

Akizuki O, Inayoshi A, Kitayama T, Yao K, Shirakura S, Sasaki K, Kusaka H \& Matsubara M 2008 Blockade of T-type voltage-dependent $\mathrm{Ca}^{2+}$ channels by Benidipine, a dihydropyridine calcium channel blocker, inhibits aldosterone production in human adrenocortical cell line NCI-H295R. European Journal of Pharmacology 584 424-434. (https:// doi.org/10.1016/j.ejphar.2008.02.001)

Azizan EA, Poulsen H, Tuluc P, Zhou J, Clausen MV, Lieb A, Maniero C, Garg S, Bochukova EG, Zhao W, et al. 2013 Somatic mutations in ATP1A1 and CACNA1D underlie a common subtype of adrenal hypertension. Nature Genetics 45 1055-1060. (https://doi. org/10.1038/ng.2716)

Barrett PQ, Ertel EA, Smith MM, Nee JJ \& Cohen CJ 1995 Voltage-gated calcium currents have two opposing effects on the secretion of aldosterone. American Journal of Physiology 268 C985-C992. (https:// doi.org/10.1152/ajpcell.1995.268.4.C985)

Barrett PQ, Guagliardo NA, Klein PM, Hu C, Breault DT \& Beenhakker MP 2016 Role of voltage-gated calcium channels in the regulation of aldosterone production from zona glomerulosa cells of the adrenal cortex. Journal of Physiology 594 5851-5860. (https://doi.org/10.1113/ JP271896)

Calhoun DA, Nishizaka MK, Zaman MA, Thakkar RB \& Weissmann P 2002 Hyperaldosteronism among black and white subjects with resistant hypertension. Hypertension 40 892-896. (https://doi. org/10.1161/01.hyp.0000040261.30455.b6)

Cherradi N, Rossier MF, Vallotton MB \& Capponi AM 1996 Calcium stimulates intramitochondrial cholesterol transfer in bovine adrenal glomerulosa cells. Journal of Biological Chemistry 271 25971-25975. (https://doi.org/10.1074/jbc.271.42.25971)

Cohen CJ, McCarthy RT, Barrett PQ \& Rasmussen H 1988 Ca channels in adrenal glomerulosa cells: $\mathrm{K}^{+}$and angiotensin II increase T-type Ca channel current. PNAS 85 2412-2416. (https://doi.org/10.1073/ pnas.85.7.2412)

Cui Y, Liu X, Yang T, Mei YA \& Hu C 2014 Exposure to extremely lowfrequency electromagnetic fields inhibits T-type calcium channels via AA/LTE4 signaling pathway. Cell Calcium 55 48-58. (https://doi. org/10.1016/j.ceca.2013.11.002)

Douma S, Petidis K, Doumas M, Papaefthimiou P, Triantafyllou A, Kartali N, Papadopoulos N, Vogiatzis K \& Zamboulis C 2008 Prevalence of primary hyperaldosteronism in resistant hypertension: a retrospective observational study. Lancet 371 1921-1926. (https:// doi.org/10.1016/S0140-6736(08)60834-X)

Dreyfus FM, Tscherter A, Errington AC, Renger JJ, Shin HS, Uebele VN, Crunelli V, Lambert RC \& Leresche N 2010 Selective T-type calcium channel block in thalamic neurons reveals channel redundancy and physiological impact of I(T)window. Journal of Neuroscience 30 99-109. (https://doi.org/10.1523/JNEUROSCI.4305-09.2010)

Enyeart JJ \& Enyeart JA 2015 Adrenal fasciculata cells express T-type and rapidly and slowly activating L-type $\mathrm{Ca}^{2+}$ channels that regulate cortisol secretion. American Journal of Physiology: Cell Physiology $\mathbf{3 0 8}$ C899-C918. (https://doi.org/10.1152/ajpcell.00002.2015)

Funder JW, Carey RM, Fardella C, Gomez-Sanchez CE, Mantero F, Stowasser M, Young Jr WF, Montori VM \& Endocrine Society 2008 Case detection, diagnosis, and treatment of patients with primary aldosteronism: an endocrine society clinical practice guideline.
Journal of Clinical Endocrinology and Metabolism 93 3266-3281. (https://doi.org/10.1210/jc.2008-0104)

Hannemann A \& Wallaschofski H 2012 Prevalence of primary aldosteronism in patient's cohorts and in population-based studies - a review of the current literature. Hormone and Metabolic Research 44 157-162. (https://doi.org/10.1055/s-0031-1295438)

Hegstad R, Brown RD, Jiang NS, Kao P, Weinshilboum RM, Strong C \& Wisgerhof M 1983 Aging and aldosterone. American Journal of Medicine 74 442-448. (https://doi.org/10.1016/00029343(83)90971-3)

Helton TD, Xu W \& Lipscombe D 2005 Neuronal L-type calcium channels open quickly and are inhibited slowly. Journal of Neuroscience 25 10247-10251. (https://doi.org/10.1523/JNEUROSCI.1089-05.2005)

Hu C, Rusin CG, Tan Z, Guagliardo NA \& Barrett PQ 2012 Zona glomerulosa cells of the mouse adrenal cortex are intrinsic electrical oscillators. Journal of Clinical Investigation 122 2046-2053. (https:// doi.org/10.1172/JCI61996)

Imagawa K, Okayama S, Takaoka M, Kawata H, Naya N, Nakajima T, Horii M, Uemura S \& Saito Y 2006 Inhibitory effect of efonidipine on aldosterone synthesis and secretion in human adrenocarcinoma (H295R) cells. Journal of Cardiovascular Pharmacology 47 133-138. (https://doi.org/10.1097/01.fjc.0000197539.12685.f5)

Lalevee N, Resin V, Arnaudeau S, Demaurex N \& Rossier MF 2003 Intracellular transport of calcium from plasma membrane to mitochondria in adrenal H295R cells: implication for steroidogenesis. Endocrinology 144 4575-4585. (https://doi.org/10.1210/en.2003-0268)

Lifton RP, Dluhy RG, Powers M, Rich GM, Cook S, Ulick S \& Lalouel JM 1992 A chimaeric 11 beta-hydroxylase/aldosterone synthase gene causes glucocorticoid-remediable aldosteronism and human hypertension. Nature 355 262-265. (https://doi. org $/ 10.1038 / 355262 \mathrm{a} 0$ )

Lotshaw DP 2001 Role of membrane depolarization and T-type $\mathrm{Ca}^{2+}$ channels in angiotensin II and $\mathrm{K}^{+}$stimulated aldosterone secretion. Molecular and Cellular Endocrinology 175 157-171. (https://doi. org/10.1016/s0303-7207(01)00384-7)

Monticone S, Burrello J, Tizzani D, Bertello C, Viola A, Buffolo F Gabetti L, Mengozzi G, Williams TA, Rabbia F, et al. 2017 Prevalence and clinical manifestations of primary aldosteronism encountered in primary care practice. Journal of the American College of Cardiology 69 1811-1820. (https://doi.org/10.1016/j.jacc.2017.01.052)

Nanba K, Vaidya A, Williams GH, Zheng I, Else T \& Rainey WE 2017 Agerelated autonomous aldosteronism. Circulation 136 347-355. (https:// doi.org/10.1161/CIRCULATIONAHA.117.028201)

Nanba K, Vaidya A \& Rainey WE 2018 Aging and adrenal aldosterone production. Hypertension 71 218-223. (https://doi.org/10.1161/ HYPERTENSIONAHA.117.10391)

Nishimoto K, Nakagawa K, Li D, Kosaka T, Oya M, Mikami S, Shibata H, Itoh H, Mitani F, Yamazaki T, et al. 2010 Adrenocortical zonation in humans under normal and pathological conditions. Journal of Clinical Endocrinology and Metabolism 95 2296-2305. (https://doi.org/10.1210/ jc.2009-2010)

Nishimoto K, Tomlins SA, Kuick R, Cani AK, Giordano TJ, Hovelson DH, Liu CJ, Sanjanwala AR, Edwards MA, Gomez-Sanchez CE, et al. 2015 Aldosterone-stimulating somatic gene mutations are common in normal adrenal glands. PNAS 112 E4591-E4599. (https://doi. org/10.1073/pnas.1505529112)

Nishimoto K, Seki T, Hayashi Y, Mikami S, Al-Eyd G, Nakagawa K, Morita S, Kosaka T, Oya M, Mitani F, et al. 2016 Human adrenocortical remodeling leading to aldosterone-producing cell cluster generation. International Journal of Endocrinology 2016 7834356. (https://doi. org $/ 10.1155 / 2016 / 7834356)$

Payet MD, Durroux T, Bilodeau L, Guillon G \& Gallo-Payet N 1994 Characterization of $\mathrm{K}^{+}$and $\mathrm{Ca}^{2+}$ ionic currents in glomerulosa cells from human adrenal glands. Endocrinology 134 2589-2598. (https:// doi.org/10.1210/endo.134.6.7515004) https://joe.bioscientifica.com https://doi.org/10.1530/JOE-19-0259 (c) 2020 The authors Published by Bioscientifica Ltd. Printed in Great Britain

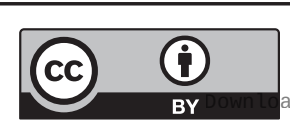

This work is licensed under a Creative Commons Attribution 4.0 International License. ded from Bioscientifica com at 04/26/2023 11:21:44AM 
Perez-Reyes E 2003 Molecular physiology of low-voltage-activated t-type calcium channels. Physiological Reviews 83 117-161. (https://doi. org/10.1152/physrev.00018.2002)

Python CP, Rossier MF, Vallotton MB \& Capponi AM 1993 Peripheraltype benzodiazepines inhibit calcium channels and aldosterone production in adrenal glomerulosa cells. Endocrinology 132 1489_ 1496. (https://doi.org/10.1210/endo.132.4.8384990)

Rossi GP 2011 A comprehensive review of the clinical aspects of primary aldosteronism. Nature Reviews: Endocrinology 7 485-495. (https://doi. org/10.1038/nrendo.2011.76)

Rossi GP, Bernini G, Caliumi C, Desideri G, Fabris B, Ferri C, Ganzaroli C, Giacchetti G, Letizia C, Maccario M, et al. 2006 A prospective study of the prevalence of primary aldosteronism in 1,125 hypertensive patients. Journal of the American College of Cardiology 48 2293-2300. (https://doi.org/10.1016/j.jacc.2006.07.059)

Rossier MF 2016 T-type calcium channel: a privileged gate for calcium entry and control of adrenal steroidogenesis. Frontiers in Endocrinology 7 43. (https://doi.org/10.3389/fendo.2016.00043)

Rossier MF, Python CP, Capponi AM, Schlegel W, Kwan CY \& Vallotton MB 1993 Blocking T-type calcium channels with tetrandrine inhibits steroidogenesis in bovine adrenal glomerulosa cells. Endocrinology 132 1035-1043. (https://doi.org/10.1210/ endo.132.3.8382595)

Rossier MF, Burnay MM, Brandenburger Y, Cherradi N, Vallotton MB $\&$ Capponi AM 1996a Sources and sites of action of calcium in the regulation of aldosterone biosynthesis. Endocrine Research 22 579-588. (https://doi.org/10.1080/07435809609043750)

Rossier MF, Burnay MM, Vallotton MB \& Capponi AM $1996 b$ Distinct functions of T- and L-type calcium channels during activation of bovine adrenal glomerulosa cells. Endocrinology 137 4817-4826. (https://doi.org/10.1210/endo.137.11.8895352)

Rossier MF, Ertel EA, Vallotton MB \& Capponi AM 1998 Inhibitory action of mibefradil on calcium signaling and aldosterone synthesis in bovine adrenal glomerulosa cells. Journal of Pharmacology and Experimental Therapeutics 287 824-831.

Scholl UI, Goh G, Stolting G, de Oliveira RC, Choi M, Overton JD, Fonseca AL, Korah R, Starker LF, Kunstman JW, et al. 2013 Somatic and germline CACNA1D calcium channel mutations in aldosteroneproducing adenomas and primary aldosteronism. Nature Genetics $\mathbf{4 5}$ 1050-1054. (https://doi.org/10.1038/ng.2695)

Schrier AD, Wang H, Talley EM, Perez-Reyes E \& Barrett PQ 2001 alpha1H T-type $\mathrm{Ca}^{2+}$ channel is the predominant subtype expressed in bovine and rat zona glomerulosa. American Journal of Physiology: Cell Physiology 280 C265-C272. (https://doi.org/10.1152/ ajpcell.2001.280.2.C265)

Stengel W, Jainz M \& Andreas K 1998 Different potencies of dihydropyridine derivatives in blocking T-type but not L-type $\mathrm{Ca}^{2+}$ channels in neuroblastoma-glioma hybrid cells. European Journal of Pharmacology 342 339-345. (https://doi.org/10.1016/s00142999(97)01495-7)

Stowasser M 2001 Primary aldosteronism: rare bird or common cause of secondary hypertension? Current Hypertension Reports 3 230-239. (https://doi.org/10.1007/s11906-001-0045-3)

Wiederkehr A, Szanda G, Akhmedov D, Mataki C, Heizmann CW, Schoonjans K, Pozzan T, Spat A \& Wollheim CB 2011 Mitochondrial matrix calcium is an activating signal for hormone secretion. Cell Metabolism 13 601-611. (https://doi.org/10.1016/j.cmet.2011.03.015)

Williams TA, Monticone S, Schack VR, Stindl J, Burrello J, Buffolo F, Annaratone L, Castellano I, Beuschlein F, Reincke M, et al. 2014 Somatic ATP1A1, ATP2B3, and KCNJ5 mutations in aldosteroneproducing adenomas. Hypertension 63 188-195. (https://doi. org/10.1161/HYPERTENSIONAHA.113.01733)

Xu W \& Lipscombe D 2001 Neuronal Ca(V)1.3alpha(1) L-type channels activate at relatively hyperpolarized membrane potentials and are incompletely inhibited by dihydropyridines. Journal of Neuroscience $\mathbf{2 1}$ 5944-5951. (https://doi.org/10.1523/JNEUROSCI.21-16-05944.2001)

Yang T, Zhang HL, Liang Q, Shi Y, Mei YA, Barrett PQ \& Hu C 2016 Smallconductance $\mathrm{Ca}^{2+}$-activated potassium channels negatively regulate aldosterone secretion in human adrenocortical cells. Hypertension $\mathbf{6 8}$ 785-795. (https://doi.org/10.1161/HYPERTENSIONAHA.116.07094)

Yang T, He M \& Hu C 2018 Regulation of aldosterone production by ion channels: from basal secretion to primary aldosteronism. Biochimica et Biophysica Acta: Molecular Basis of Disease 1864 871-881. (https://doi. org/10.1016/j.bbadis.2017.12.034)

Received in final form 7 October 2019

Accepted 25 October 2019

Accepted Manuscript published online 25 October 2019 https://joe.bioscientifica.com https://doi.org/10.1530/JOE-19-0259 (c) 2020 The authors Published by Bioscientifica Ltd. Printed in Great Britain

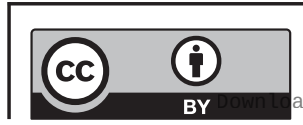

This work is licensed under a Creative Commons Attribution 4.0 International License.

ded from Bioscientifica.com at 04/26/2023 11:21:44AM 